\title{
Curriculum Decolonisation and Revisionist Pedagogy of African Customary Law
}

\section{AC Diala*}

\section{P.E.R}

Pioneer in peer-reviewed, open access online law publications

Author

Anthony C Diala

Affiliation

University of the Western Cape South Africa

Email adiala@uwc.ac.za

Date Submission

18 April 2018

Date Revised

20 September 2019

Date Accepted

20 September 2019

Date published

13 November 2019

Editor Prof M Carnelley

How to cite this article

Diala AC "Curriculum

Decolonisation and Revisionist

Pedagogy of African Customary Law" PER / PELJ 2019(22) - DOI http://dx.doi.org/10.17159/17273781/2019/v22i0a4976

\section{Copyright}

\section{DOI}

http://dx.doi.org/10.17159/1727-

3781/2019/v22i0a4976

\section{Abstract}

Fees-related protests in South African universities have pushed the decolonisation of the law curriculum to the front burner of academic discourse. As part of the curriculum, African customary law was marginalised in the courts, distorted by policy makers, and largely labelled as unfriendly to women and younger male children in issues of marriage, property, and succession. However, this normative system is shaped by the manner in which people adapt norms with agrarian origins to the socio-economic changes caused by colonial rule. In this historical context, scholars focus more on conflict of laws than on people's adaptation of indigenous norms to socioeconomic changes. So, in what ways should universities handle the pedagogy of African customary law? This article argues that colonialism endowed Africans with a new socio-legal identity, which questions the mainstream conceptualisation of customary law into "official" and "living" versions. Accordingly, the law curriculum should reflect this new identity and acknowledge the self-sustaining legacy of colonialism as a reality check on decolonisation. As the article suggests, reconceptualising African customary law offers a framework for legal integration, especially in South Africa.

\section{Keywords}

African customary law pedagogy; curriculum decolonisation; academic literacy; student protests. 
Fellow educators - are we not lost?

Do we know where we are?

Remember where we have been,

Or foresee where we are going? ${ }^{1}$

\section{Introduction}

Although policy makers have long acknowledged the existence of challenges in legal education in sub-Saharan Africa, ${ }^{2}$ the relevance of the university curriculum came under intense scrutiny only as one of the issues raised by students' protests in South Africa. ${ }^{3} \mathrm{~A}$ notable demand of these protesters is curriculum decolonisation, an issue that has captured the attention of scholars and policy makers in the last few years. For example, at the Higher Education Summit of October 2015, the Minister of Higher Education, Science and Technology, Blade Nzimande, called on universities to "shed all the problematic features of their apartheid and colonial past." Largely due to its limited scope ${ }^{4}$ this paper's contribution to the decolonisation debate is confined to a single question: In what ways should universities handle the pedagogy of African customary law? ${ }^{5}$ One key reason informs this focus on customary law.

As the introductory quote above shows, the relevance of the curriculum is usually questioned when teachers fail to connect their teaching to the larger society. Just like indigenous knowledge systems, African customary law bore and arguably still bears the burden of marginalisation, derision, and distortion in our classrooms. ${ }^{6}$ Indeed, it has taken several post-colonial decades for it to become compulsory in some law schools. Since customary law affects the lives of most Africans, it affects African legal identity. In this sense, it occupies a unique place in the debate on the decolonisation of the

Anthony C Diala. PhD (UCT) LLM (UP) PG Dip (NLS, Abuja) LLB (Enugu State University). Senior lecturer, University of the Western Cape, South Africa. E-mail: adiala@uwc.ac.za. I acknowledge the financial assistance of the African Humanities Programme of the American Council of Learned Societies.

Huebner "Poetry and Power" 231.

See, for example, lya 2003 Third World Legal Stud 141; Modiri 2014 Acta Academica 2; Greenbaum 2012 Stell LR 16-18.

3 Disemelo 2015 https://mg.co.za/article/2015-10-29-student-protests-are-aboutmuch-more-than-just-feesmustfall.

$4 \quad$ For the epistemology of curriculum decolonisation and its race and class struggle elements, see Le Grange 2016 SAJHE.

$5 \quad$ "Customary law" sounds derogatory (Mamdani Define and Rule 6, 20). Given the author's view that African customary law is constructed from the adaptation of indigenous norms to socio-economic changes, the reader should expect the usage of the term in this article to sometimes appear confusing, and for it to be used in both the singular and the plural senses. Himonga 2010 PSILR 54. 
law curriculum. Here, pertinent questions on academic literacy include the following: What should teachers teach as African customary law? What socio-legal theories should inform African customary law pedagogy? By which methods should it be assessed ${ }^{7}$ Exploring these questions would be unrealistic unless the meaning of decolonising the university curriculum is unpacked.

For this purpose, I look to Pinar's description of curriculum theory as "the interdisciplinary study of educational experience."8 Here, educational experience encompasses the attitudes, values and perceptions that inform the stories teachers tell students about their past, present, and future. ${ }^{9}$ As Arendt argued in the context of the United States, it demands that teachers, as representatives of the world that learners enter, take responsibility for learning by presenting it accurately and fairly. ${ }^{10}$ In this sense, the literature on curriculum decolonisation reveals that the university curriculum is perceived as a carrier of colonialism. ${ }^{11}$ Conversations on this subject trace this perception to the Eurocentric design of the curriculum and its suppression of African world views. ${ }^{12}$ Much of this suppression lies in the pursuit of academic literacy through foreign languages such as English, French, and Portuguese. For example, Boughey and McKenna show how the dominance of the autonomous model of literacy in South Africa divorces students from their social contexts by perceiving "language use as the application of a set of neutral skills". ${ }^{13}$ Demands for curriculum decolonisation therefore seek to end "the domination of Western epistemological traditions, histories and figures", and instead to focus on works by Africans about African problems. ${ }^{14}$ These demands are fuelled by perceptions of injustice, oppression and, arguably, confused identity, which persisted at the end of colonial rule and apartheid. Indeed, the demands for decolonisation demonstrate the slow pace of transformation in postcolonial and post-apartheid structures. As Mbembe observes, "there is something

7 To reflect the views of many students I interacted with, one might also add the issue of the qualifications and/or training of those who teach African customary law.

Pinar What is Curriculum Theory? 2

Grumet "Restitution and Reconstruction of Educational Experience."

Arendt "Crisis in Education."

For example, see Smith Decolonising Methodologies; Letsekha 2013 IJTL 8.

Theconversation.com is a popular forum. See, for example, Mgqwashu 2016 https://theconversation.com/universities-cant-decolonise-the-curriculum-withoutdefining-it-first-63948; Wingfield 2017 http://theconversation.com/what-decolonisededucation-should-and-shouldnt-mean-72597.

13 Boughey and McKenna 2016 CriSTaL 1, 3.

$14 \quad$ Molefe 2016 World Policy J 32. 
profoundly wrong when ... syllabuses designed to meet the needs of colonialism and apartheid ... continue well into the liberation era."15

The law curriculum does not escape Mbembe's observation. The four-or five-year LLB programme, which is the standard qualification for lawyers, is heavily Eurocentric. ${ }^{16}$ Its Eurocentrism is unsurprising, given that the LLB programme mirrors the format in other Commonwealth universities. ${ }^{17}$ Notably, the content of Jurisprudence largely neglects African philosophy, except for recent efforts towards ubuntu theorisation in South Africa. ${ }^{18}$ Since descriptions of curriculum decolonisation seek to highlight African worldviews, I offer a revisionist pedagogy of law as a starting point for attaining this objective. In what follows, I contextualise legal revisionist pedagogy and outline the structure of this article.

\subsection{Problem context}

Law teachers are not extra-terrestrials. Rather, they are products of an unyielding Western cultural indoctrination that begins from infancy. Consequently, they deliver the law curriculum in terms of their knowledge of law's history and role in society. Given the conscious and unconscious presentation of colonialism as a civilising mission, ${ }^{19}$ it is easy for law teachers to neglect the fact that colonialism is an inhumane, predatory enterprise, which left an irreversible mark on law and society in Africa. Arguably, one of its most notable marks was left on African customary law. Until recently this subject was not taught in an interdisciplinary way that links to subjects such as theology, sociology, political science, economics, and anthropology. ${ }^{20}$ Importantly, it is still largely perceived to be hostile to women and younger male children, especially in the spheres of marriage, property, and succession. However, aside from the modest literature on colonial and apartheid distortions of African customs, scholars and policy makers rarely emphasise how customary law's perceived hostility flows from the dissonance between its agrarian, communal features and its application in modern, individualistic conditions. Furthermore, the mainstream conceptualisation of African customary law is criticised as

Mbembe 2016 AHHE 32.

16 Wildenboer 2010 Fundamina gives a historical account of the legal profession in South Africa.

lya $2001 \mathrm{~J}$ Leg Ed 359.

Muvangua and Cornell Ubuntu and the Law; Mokgoro 1998 PELJ.

Mudimbe 1985 Afr Stud Rev 181; Bain 2003 Int Relat 64-65; Mamdani Citizen and Subject 220.

20 Admittedly, this non-interdisciplinary accusation can also be levelled against other law subjects. 
ambiguous ${ }^{21}$ while conflict of normative orders encourages an antipodal approach to customary law's interaction with state law. ${ }^{22}$ In the foregoing context, is it realistic to decolonise the law curriculum without reversing the manner in which law teachers project the identity of African customary law? Drawing primarily from field insights in South Africa and Nigeria, this article uses the didactic tool of legal revisionism to anchor two arguments.

Legal revisionism, as explained in Part III below, illustrates the need for a reality check in the decolonisation debate. This reality check may be referred to as an African legal identity crisis. The failure of mainstream legal scholarship to explain the impact of colonialism on the African psyche is evident in scholars' ambiguous categories of official and living customary law. ${ }^{23}$ While they define official customary law as the version perceived by observers, especially legal experts, outside the community in which the concerned norms are observed, they define living customary law as the norms that regulate people's daily lives. ${ }^{24}$ Such intrinsically insular categorisation misses two crucial points. Firstly, the self-replicating effects of the colonial experience on Africans are so radical that the commencement of colonial rule arguably ushered in a new normative era. As a normative historical marker, therefore, Africa's colonial experience demands a distinction between indigenous African law and African customary law. ${ }^{25}$ While indigenous laws are surviving precolonial norms which people still observe in their ancient forms, customary laws are adaptations of these ancient norms to legal, religious, economic, and cultural changes. Secondly, the mainstream categorisation of customary law ignores the impact of the interaction between of legal orders on the normative behaviour of people who observe indigenous laws. ${ }^{26}$ Indeed, this categorisation was arguably prompted by state recognition of norms with agrarian origins without due consideration of the foundational values that shape(d) their adaptation to socioeconomic changes. If attention is focussed on the manner in which these foundational values inform African people's

\footnotetext{
21 For a critique of customary law's conceptualisation, see Diala $2017 \mathrm{~J}$ Legal Plur.

22 State law is essentially transplanted European laws adopted or adapted to local circumstances.

23 For a sample of this categorisation, see Himonga and Bosch 2000 SALJ 319; Bennett '"Official' vs 'Living' Customary Law"; Bekker and Van Niekerk 2010 THRHR 679; Bekker and Maithufi 1992 JJS; Van Niekerk 2012 SUBB Jurisprudentia 6.

24 As above.

25 Indigenous African law and African customary law are used in both the singular and the plural senses.

26 Diala 2017 J Legal Plur 152.
} 
encounter with modernity, the labels of "official" and "living" customary law become unnecessary. These two points will be expanded in Part II.

Furthermore, law, especially customary law, should be taught with a revisionist outlook. Revisionist pedagogy exposes colonialism as an imperialistic enterprise, rather than as the civilising mission that is often portrayed to students. ${ }^{27}$ Colonialists (and their citizens) saw nothing wrong with seizing African natural resources, dividing the loyalties of African peoples, exploiting their ethno-religious divisions, and killing those who resisted them. For example, Belgium's King Leopold II cruelly plundered the Congo territories in a manner unparalleled in recent history, thereby contributing "in a large way to the death of perhaps 10 million innocent people". ${ }^{28}$ Yet very little of his murderous looting is heard in classrooms. Significantly, Africans accepted colonial indoctrination, which manifests in a relentless demand to become more Western in thought, language and, of course, learning. This acceptance, which Odora-Hoppers and Richards labelled "second generation colonialism", 29 largely remains with us. Despite the noise made about the decolonisation of the university curriculum in the last few years, colonialism is not being unmasked as a successful ideological struggle for African beliefs (religion), way of life (culture), and perception of the world (philosophy). Part III shows why a revisionist pedagogy of African customary law is required for a meaningful engagement with other subjects that form part of the law curriculum. In Part IV several suggestions regarding this revisionist pedagogy are offered. The article ends by drawing attention to the potential value of re-conceptualising African customary law.

\section{The identity of African customary law}

Historically, universities symbolised the nation-state, and served them by promoting and protecting their cultural identity. ${ }^{30}$ This historical mission explains why European settlers in Africa established universities primarily as symbols, servers, and shippers of the European brand of civilisation in European colonies. ${ }^{31}$ The stress on "European" is deliberate. Europeans modelled the architecture of African universities on their own universities;

27 The imperial anthem, "Rule Britannia, Britannia rule the waves ..." is still widely admired by university students on YouTube.

28 Hochschild King Leopold's Ghost; Dummett 2004 http://news. bbc.co.uk/2/hi/africa/3516965.stm.

$29 \quad$ Odora-Hoppers and Richards Rethinking Thinking 7.

$30 \quad$ Readings University in Ruins chs 2 and 3.

$31 \quad$ Mamdani "Decolonising the Post-colonial University"; Pietsch Empire of Scholars pt 1. 
they drew most of their faculty from Europe, and, of course, designed their curricula using European models. Readings gave an excellent analysis of how these universities evolved from three eras. These eras are reason, culture, and excellence. ${ }^{32}$ Significantly, European universities were still in the second era when they were exported to Africa. As integral aspects of the colonial project, therefore, the curricula of African universities "played an instrumental role [in] promoting and imposing the Eurocentric 'ways' and worldviews while subjugating everything else." 33 Given their foundations, these universities left a huge mark on the African intellectual psyche. In numerous schools, for example, teachers favour Plato and Shakespeare over Chinua Achebe, Ngugi wa Thiong'o, and Ayi Kwei Armah. Literary critics of white supremacy such as Peter Abrahams, Miriam Tlali, Alex La Guma, and Nadine Gordimer were banned or simply ignored.

However, the university is only one aspect of a systematic and highly successful cultural promotion of Western supremacy. Indeed, one could say that this promotion was driven by conscious efforts to "erase the historical, intellectual and cultural contributions of Africa and other parts of the 'nonWestern' world to our common humanity." 34 In this respect, Kelley notes: ${ }^{35}$

The colonial mission to 'civilize' the primitive is just a smoke screen. If anything, colonialism results in the massive destruction of whole societiessocieties that not only function at a high level of sophistication and complexity, but that might offer the West valuable lessons about how we might live together and remake the modern world.

Limitations of space discourage a full exposition of the impact of colonialism on the African psyche. ${ }^{36}$ To highlight a few, Africans used Christianity to nullify the female deity prevalent in many communities, thereby entrenching patriarchy with its focus on "a male God, his son, his bishops and priests". ${ }^{37}$ Africans shaped their worldview with franchises and movies such as Star Wars, James Bond, and The Good, the Bad and the Ugly. They heard their elders say frequently - and with great admiration - that "the white man is

32 Readings University in Ruins (the erosion of state sovereignty by globalisation turned universities into transnational corporations, forcing them to replace national culture and identity with the discourse of capitalist "excellence"). Heleta 2016 Transformation in Higher Education 2.

Heleta 2016 Transformation in Higher Education 2.

Kelley "Poetics of Anticolonialism".

For intellectual responses to colonialism in South Africa, see Masilela "African Intellectual and Literary Responses".

37 Amadiume Male Daughters, Female Husbands 123 shows how "indigenous customary laws associated with woman-to-woman marriage became confused as a result of its reinterpretation according to cannon law and Christian morality". See ch 8 titled "The Erosion of Women's Power" 134. 
god". They imbibed lifestyles alien to humanistic African values, and acquired a frightening sense of inferiority to people who had pillaged their resources and killed, raped, and maimed their ancestors. As the editor of Current Affairs noted in 2017, "One of the cruellest aspects of colonialism is the way it forces the colonized into servility and obedience". ${ }^{38}$ Today, not many appreciate that "colonial domination required a whole way of thinking, a discourse in which everything that is advanced, good and civilised is defined and measured in European terms". 39 The impact of colonialism is so enduring that literature on Greek and Roman history dominate many African libraries, while some history books still teach that Mungo Park discovered the River Niger. Naturally, law did not escape the cultural impact of colonialism. So, the issue is not whether colonialism altered the identity of indigenous African laws. The issue is the extent of this alteration.

\subsection{What the scholars say}

On the one hand, scholars like Chanock and Snyder have argued that customary law is not a remnant of the pre-colonial past. ${ }^{40}$ Rather, it is the product of normative struggles between various interest groups during and after the colonial period. ${ }^{41}$ These struggles range from property contestations to political power grabbing and claims of gender superiority. A brief illustration of the context of these struggles will suffice. Put simply, European colonialists encountered African men who were understandably suspicious of their motives, or anxious to subjugate their wives. ${ }^{42}$ They met chiefs and elders who claimed powers they never exercised, or magnified the source, purpose, and range of their powers. ${ }^{43}$ They also met ambitious Africans who, metaphorically, jumped into bed with their economic and political aims. ${ }^{44}$ Significantly, the colonialists generally wanted to maximise their economic exploitation of the natives and discourage rebellion. ${ }^{45}$ Accordingly, they were not overly concerned with the veracity of the customs presented to them. ${ }^{46}$ These presentations of customs, the processes of interpreting customs in the courts, and the systematic cultural, educational, and spiritual indoctrination of Africans subject to indigenous

38

39

40

41

42

43

44

45

46

Robinson 2017 https://www.currentaffairs.org/2017/09/a-quick-reminder-of-whycolonialism-was-bad. Also see Césaire "Discourse on Colonialism" 43.

Kelley "Poetics of Anticolonialism".

Chanock Law, Custom and Social Order; Snyder $1981 \mathrm{~J}$ Legal Plur 76.

Claassens 2011 Acta Juridica 176.

Nwanesi Development, Micro-credit and Women's Empowerment 36-37.

Chanock Making of South African Legal Culture ch 12.

Mamdani Citizen and Subject 17.

Commission of Enquiry Report 24-30.

Holleman 1973 Law \& Soc Rev 607. 
law influenced the construction of African customary law. Seen from this "construction" viewpoint, the pre-colonial identity of African customary law is lost.

On the other hand, there are some scholars who believe that indigenous African laws retain their pre-colonial identity, and therefore deserve protection from the incursions of state law. ${ }^{47}$ Ostensibly goaded by conflict of normative orders, these scholars raise alarm at legislative interventions affecting indigenous law. ${ }^{48}$ This protectionist attitude underlies the mainstream classification of customary law into living and official versions, with the perhaps unintended impression that living customary law is authentic, while official customary law is inauthentic. For the reasons given below, the categorisation of customary law into "official" and "living" versions demonstrates the confused legal identity of Africans.

\subsubsection{A misplaced categorisation}

It is easy to sympathise with the justifications for the scholarly categorisation of African customary law. From the late eighties, studies by the Women and Law in Southern Africa Research and Education Trust (WLSA) began to highlight disparities between the customs observed by people and those recognised by postcolonial, post-apartheid governments. Specifically, WLSA's research "exposed the state-recognised customary law in Southern Africa as not only rigid, but also largely distorted versions of the precolonial, pre-apartheid customary law."49 Significantly, this perception of customary law is not exclusive to southern Africa. A historian noted that the court clerks who acted as interpreters to Warrant Chiefs and District Commissioners in Nigeria were "generally men of 'little dangerous knowledge"'.50 Often, their limited language abilities, pecuniary interests and power motives influenced their presentation of indigenous law to British officials. ${ }^{51}$ Their reconstruction of indigenous norms was clearly evident in the widespread misrepresentations of gender relations from relational to hierarchical. ${ }^{52}$ However, the empirical reality is that distortions of customs form part of the adaptation of indigenous law to socio-economic changes. As explained

See, for example, Kult 2000 Ind Int'l \& Comp L Rev; Pieterse 2000 De Jure; Rautenbach and Du Plessis "Reform of the South African Customary Law of Succession" 336-360.

48 For reference to these authors, see Himonga "Future of Living Customary Law".

$49 \quad$ Diala $2017 \mathrm{~J}$ Legal Plur 143.

50 Afigbo Warrant Chiefs 111.

$51 \quad$ Afigbo Warrant Chiefs 106-107; Akoma 2009 Res Afr Lit 90-92.

52 Walker Women and Gender; Hafkin and Bay Women in Africa 55; Achebe Farmers, Traders, Warriors, and Kings 164-171. 
below, other than religious laws and the imposed European laws that became state laws, there are only two categories of African laws: indigenous law and customary law.

As stated in part I, indigenous laws are ancient norms which people still observe in their precolonial forms. Many of these norms, like human sacrifices, widowhood cleansing and regicide are fast disappearing because they are no longer suited to modern conditions. Others like the male primogeniture rule and women's lack of matrimonial property rights persist because they find support in some attitudes and social settings. Put differently, some indigenous laws survive for various reasons such as tradition, agrarian livelihoods, state recognition (example, codifications, restatements, and precedents), and people's failure to exercise agency to assert change. For example, in the past, property was administered by the oldest male in the family largely because the security of the family required a strong leader who was capable of defending the household from enemies and certain not to leave the family (to marry into another family). ${ }^{53}$ Furthermore, male heirs used deceased persons' estates to care for women and children because the agrarian, close-knit nature of society left them no choice. ${ }^{54}$ Today, socio-economic changes such as acculturation, urbanisation and the changing forms of property make it difficult for heirs to fulfil their duty of care, thus leading to agency-driven changes in the application of many customs. The normative build-up to these changes created a dissonance between people's practices and government perceptions of customs, thereby prompting references to living customary law. But these references are unnecessary.

If norms are "living" merely because they are being observed, then one may argue that all laws such as criminal and commercial laws are living. Yet no one refers to living criminal law or living commercial law. Indeed, this analogy implies that the male primogeniture rule, which is commonly regarded as official customary law, would be living law because it is widely observed in sub-Saharan Africa. ${ }^{55}$ Primarily because male primogeniture is

Mbatha 2002 SAJHR; Okoro Customary Laws of Succession 4-6.

Diala 2014 AHRLJ.

This is evident in litigants' contestations. See, for example, Bhe $v$ Magistrate, Khayelitsha; Shibi v Sithole; South African Human Rights Commission v President of the Republic of South Africa 20051 SA 580 (CC); Onyibor Anekwe v Mrs Maria Nweke 2014 All FWLR (Pt 739) 1154; Ukeje v Ukeje 201411 NWLR (Pt 1418) 384-414. See also Mbatha 2002 SAJHR. 
ossified in codes, textbooks, and precedents, it has borne the brunt of criticisms of African customary law by judges and academics. ${ }^{56}$

Furthermore, living customary law is widely acknowledged to be flexible, a feature that supposedly distinguishes it from official customary law. ${ }^{57}$ However, precedents and codifications are not cast in stone wherever there is political or judicial will for change. Importantly, the living and official categories of customary law are products of people's attitudes to indigenous law. Here, people include official and private actors, in line with the blurred nature of normative behaviour in contemporary social fields. Communities and officials engage in adaptation of norms to socio-economic changes, thereby making the living and official versions of customary law indistinguishable. ${ }^{58}$ Accordingly, there is no need to append the word "living" to African customary law, since customary law was irrevocably affected by the radical socio-economic changes caused by colonial rule.

As argued here, colonialism's introduction of socio-economic changes was so disruptive that it marked a new normative era for Africans. These changes forced adjustments in the behaviour of Africans, of which customary law is the product. While indigenous law represents precolonial norms untouched by these adjustments, customary law is constructed by its observers, arbiters, and regulators. This construction process, which is driven by people's adaptation of indigenous norms to socio-economic changes, should reflect in the pedagogy of customary law. By so doing, it will expose the altered identity of African customary law.

In what follows, the foregoing arguments are further strengthened with a brief analysis of the major influences on the identity of African customary law.

\subsection{Major influences on customary law's identity}

The first influential element is urbanisation. Colonial rule changed the agrarian social settings in which indigenous laws emerged and replaced these settings with the modernity we know today. There seems to be inadequate appreciation of the dissonance between communalistic customs that emerged in these agrarian settings and our individualistic modern settings. ${ }^{59}$ In any case, it is unrealistic to expect agrarian norms to remain

\footnotetext{
$56 \quad$ Hinz "Bhe v the Magistrate of Khayelitsha" 274-276.

$57 \quad$ Himonga and Bosch 2000 SALJ 319.

$58 \quad$ Diala $2017 \mathrm{~J}$ Legal Plur 152.

$59 \quad$ Nhlapo 1991 Acta Juridica 138, 141, 145-146.
} 
unaffected after encountering radical changes such as bridges, mines, airports, industrialisation, migrant labour, independent income, and Western education. Poor appreciation of the dissonance between modernity and customary laws' origins manifests in the hypocritical attitudes towards changes in indigenous law. An example of these attitudes manifested during this author's focus group discussions with traditional leaders in 2015. During one meeting, Chief A vehemently opposed women's right to matrimonial property, shouting, "[t]his is not our custom! It is not what our forefathers practiced!" Countering him on the need for change, Chief B pointed out that Chief A was resisting change even though he was speaking English, a foreign language, was wearing designer shoes from Italy, and clutching car keys made in Germany. He went on to explain that the customary law of matrimonial property developed in social settings in which income was jointly produced and women were re-absorbed into their families after divorce. He gave examples of women from their community who sustain their husbands with their independent income, pointing out the "wickedness" and "absurdity" of denying them property after divorce. ${ }^{60}$

Chief B's argument demonstrates the futility of protectionism in issues concerning the reform of indigenous laws. Even when the core elements of some customs remain, their applications do change. For example, in many West African communities, the presence of the groom at his wedding may be replaced with his father or brother if he is far away, while empirical studies reveal women's increasing claims to land in southern Africa. ${ }^{61}$

The second element that shaped the identity of African customary law is the staggering impact of state law on normative behaviour. Undoubtedly, colonial rule in Africa (just as elsewhere) was marked by wholesale transplantation of European laws, which eventually transformed into state laws. Legal theorists know too well that legal transplant in Africa was accompanied by a rule-based, evidence-focussed approach to law. ${ }^{62}$ In this context, Herbert Palmer, a colonial official, noted in his memoirs that customary courts in Nigeria (known then as Native Courts) "developed in a manner quite contrary to the spirit in which they were designed" and that efforts to preserve customary law "has so far resulted in steadily destroying it". ${ }^{63}$ Palmer went on to add that "among these relatively primitive peoples, Europeanised individualistic government is being introduced [and] [t]he

61

62

63

"Wickedness" and "absurdity" are the closest English translation of the words of Chief B, who though educated in Scotland spoke lgbo language peerlessly.

Claassens 2013 J Agrar Change; Claassens and Weeks 2009 SAJHR.

See, for example, Okoth-Ogendo 1984 Int'I J Soc $L$.

Afigbo 1965 JHSN 298. 
Government machinery is steadily grinding to powder all that is native". ${ }^{64}$ In South Africa, state law's influence on customary law is well known in legislation such as the Recognition of Customary Marriages Act, the Reform of Customary Law of Succession and Regulation of Related Matters Act, and the Promotion of Equality and Prevention of Unfair Discrimination Act. ${ }^{65}$

Considering the pervasive influence of state law, the interaction of legal orders, better known as legal pluralism, should influence the definitional pedagogy of African customary law. Put differently, the interpretation and application of customs by judges and litigants in intersecting social fields form part of indigenous norms' adaptation to socio-economic changes. In these interactive social fields, state laws and indigenous laws speak to each other, thereby rendering the label of official customary law absurd. ${ }^{66}$ Indeed, some judgements reflect people's adaptation of customs to socio-economic changes because the judges often operate in the same normative field as the litigants. ${ }^{67}$ It is hardly disputable that indigenous law does not apply in isolation of transplanted state laws. As Claassens urges, close attention should "be paid to issues arising [from] intersections between customary law, the formal legal system, and the Constitution." ${ }^{68}$ It is pointless to persist with the labels of official and living customary law, thereby sending judges on unrealistic quests to discover the living customary law. Rather, judges should focus on whether and to what extent litigants and communities utilise(d) the foundational values of indigenous law to adapt their customs to socio-economic changes. These values include "humaneness, family continuity, the duty of care owed to family members by the family head, the non-individual nature of marriage, and the preservation of the ancestral home."69

It is necessary for students, who ultimately are tomorrow's judges, to discover the influences behind the new identity of African customary law. Acknowledging these influences, Claassens notes how conceptualisations which "seek to insulate customary law from other values and legal rights so that it can 'develop uncontaminated' at the local level fail to recognise the processes of integration, assimilation, and change that are underway in

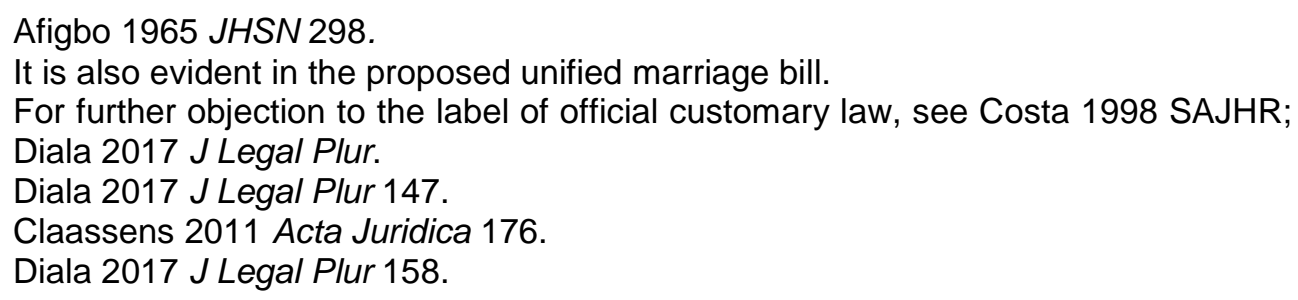


rural areas." ${ }^{170}$ So, in what ways should law teachers approach African customary law?

\section{Legal revisionist pedagogy}

The pedagogy of African customary law should be revisionist. Revisionism usually conjures up images of reversing or denying negative history. An example that readily comes to mind is denial of the Holocaust or its major actors and casualties. However, reversing negative history is only one sense of revisionism. The other sense, which is used here, is different. It concerns the reversal of prevalent narratives or views based on new evidence or self-awareness. For example, Pluto was classified as one of nine planets in our solar system for over 70 years until 2006 when members of the International Astronomical Union demoted it. ${ }^{71}$ In this sense of improving knowledge, legal revisionism may be described as a concept that challenges orthodox legal ideas to re-tell them and adapt them to new evidence. In the context of decolonising the law curriculum, legal revisionism embodies three elements.

\subsection{New legal scholarship}

Firstly, legal revisionism addresses the failure of mainstream legal scholarship to acknowledge the irremediable alteration of the identity of indigenous law. How can the law curriculum be decolonised without unmasking the successful way in which colonialism westernised the African mind? Could it be that unmasking the pervasive impact of colonialism will reveal that the problem lies not in the content of the law curriculum per se, but in how teachers present the curriculum? Other than indoctrination with Western knowledge, especially Christianity and its concept of a white saviour, the most significant impacts of colonial rule in Africa are mainly redrawn borders, ethnic conflicts, and the transplanting of industrial laws onto agrarian political economies..$^{72}$ None of these impacts can be reversed. Instead, they draw attention to the normative consequences of imposing relatively industrial political economies on largely agrarian societies.

Before the advent of colonial rule in Africa, "adaptive social change was a reality evident in nomadic settlements, inter-communal trade, conflicts, and marriages. Colonial rule amplified these changes". ${ }^{73}$ It is illogical to expect

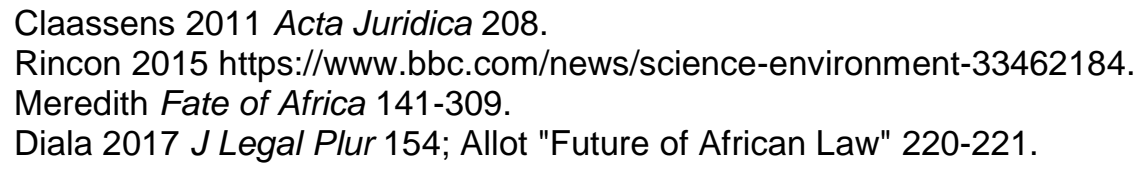


the identity of indigenous African laws to remain unaffected after encountering changes as monumental as those brought about by colonial rule. As Woodman observed, there is fair agreement that although "customary law has long existed, [it] has never been static. It has always been in processes of development and adaptation, although in recent times social change has occurred more swiftly."74 The law curriculum is a child of colonialism, along with the rules governing the application of indigenous law in the courts. Undeniably, generations of African jurists and law teachers have grown up with excellent knowledge of the Western laws masquerading as state law, and comparatively poor knowledge of indigenous African laws. Judges and teachers can only interpret, teach and perpetuate their knowledge of the law. Legal revisionism therefore requires law teachers not only to re-learn but also to stimulate and enrich students' interest in and knowledge of legal history. A sound knowledge of African legal history, an indispensable aspect of revisionist pedagogy, will enable law teachers to highlight how African customary law was constructed in and outside the courts. ${ }^{75}$ A pedagogical resource would be what is referred to as "African Archives" or "Black Archives" which feature the works of indigenous African scholars. These works shed light on the historical roots of colonial law, especially the concept of state sovereignty and its associated rule-based approach to law. In this sense, legal revisionist pedagogy has significance for law courses other than customary law.

For example, in Legal History, law teachers should be able to show, with respect to human rights, the link between the notion of individual rights and the Christian notion of (individual) salvation. ${ }^{76}$ In Contract, they should explain the evolution of employer-employee relations from slavery and serfdom. In Property Law, they should show the similarities between the communal nature of pre-colonial African customary law and Anglo-Saxon law, especially how an individual's actions were submerged under his or her kinship group. ${ }^{77}$ In Jurisprudence, they should demonstrate how legal positivism or a rule-focussed approach to law is an offshoot of power and control, specifically the violent dominion of state sovereignty. ${ }^{78}$ In Evidence, they should demonstrate how legal positivism manifested in evidentiary

Woodman 1996 J Afr L 156; Koyana Customary Law.

Kunbuor 2002 Journal of Dagaare Studies 1; Chanock 1989 IJL\&F 72-73.

Villa-Vicencio $2000 \mathrm{~J}$ L \& Relig; Douzinas 2002 MULR.

Pollock and Maitland History of English Law; Plunkett Concise History of English Law (showing how security, justice, oaths, marriage, ward-ship, and succession were regulated by the law of kinship).

78 As Derrida argues, the original power of the state is founded on violence that not only "requires the origin to repeat" its originality, but also "to alter itself so as to have the value of origin, that is, to conserve itself". See Derrida "Force of Law" 13, 43. 
rubrics, ${ }^{79}$ and how this manifestation heavily influences the judicial interpretation of (indigenous) law. For example, they should reveal how positivism induces judges to prefer the legal certainty of documentary evidence over the oral nature of indigenous law. They should be able and willing to show how positivism often neglects the values that underlie indigenous law, guides its application, and informs its adaptation to socioeconomic changes. The willingness and competence of law teachers to explain the history of law are crucial to the pedagogy of African customary law. As Snyder, put it, "[t]he concept of 'customary law' ... manifested an attempt to reinterpret African legal forms in terms of European legal categories." ${ }^{80}$ It is therefore difficult to decolonise the law curriculum without adequately explaining the historical forces that shaped and still shape the identity of customary law.

\subsection{A new legal identity}

Secondly, legal revisionism demands the conceptualisation of African customary law as the product of people's usage of indigenous African laws. Put starkly, customary law is what people do, and what people do includes official and private behaviour. ${ }^{81}$ Importantly, what African people do now is not what they used to do prior to colonial rule. All over the African continent people have adopted Western-style technology, religion, education, politics, culture, and philosophy. This pervasive westernisation has influenced the identity of customary law, given that law is inseparable from society.

As argued here, conceptual confusion over the identity of African customary law reflects in its categorisation into official and living versions. As suggested, the pedagogic label of official customary law should be dropped because the problems that prompted the label lie elsewhere. Much has been made of the distortion of indigenous African norms by colonial and apartheid authorities, who colluded with African chiefs and elders. ${ }^{82}$ These distortions were encouraged and informed by three elements.

These are rule-based judicial interpretations of indigenous law, judges' reliance on old textbooks and precedents, and struggles for power and resources in the emergent colonial social relations. These three elements intersect(ed) with little or no consideration for the foundational values of indigenous law, thereby causing hardship to groups such as women and

Hart 1958 Harv L Rev.

Snyder $1981 \mathrm{~J}$ Legal Plur 76.

Hund 1998 ARSP.

See, for example, Chanock Law, Custom and Social Order. 
younger male children. If we accept that law emerges from society's ideas of acceptable conduct, it becomes clear that most of the ideas which informed the emergence of indigenous law are no longer compatible with urbanisation, individualism, independent income, and nuclear families. In this sense, the problem with African customary law is primarily its valuestripped application in social settings markedly different from the agrarian origins of indigenous law. To address this problem, therefore, policy makers should focus on the ways in which people adapt indigenous norms to socioeconomic changes. The products of these adaptations constitute customary law, while norms applied in their ancient formats constitute indigenous laws. This re-conceptualisation illumines the identity of African customary law and reveals the futility of decolonising the law curriculum.

\subsection{Unrealistic expectations}

Many scholars have called for decolonisation to start from the mind because they recognise the alarming extent to which colonialism formatted African minds. ${ }^{83}$ Realistically, decolonising the mind begins with self-awareness. This involves acknowledgement that Africa's contemporary legal identity was constructed by European colonialists. However, it also involves an acknowledgement of the disadvantages of the legal order foisted by the colonialists, as well as a critique of its motives. Accordingly, teachers concerned with decolonisation should debunk colonialism as a civilising mission and call out Western hypocrisy in international relations and human rights. Gutto cites several examples of this hypocrisy. ${ }^{84}$ They include discriminatory referrals to the International Criminal Court, the hosting of funds stolen from Africa in Western banks, the disdainful way Europeans treat calls for reparations to be paid for slavery/colonialism, and the piracy prosecutions of East Africans for defending their own waters against exploitative foreign fishing. To these may be added the devastation caused by Western-inspired wars in the last two centuries, the nuclear and ecological threat hanging over our planet due to Western technology, and the mockery of equality in human rights treaties by the five permanent members of the United Nations Security Council. Yet, Western law, philosophy, and democracy are touted as the model in our classrooms. Revisionist pedagogy of law must not only deconstruct the Western knowledge hegemony, it must also emphasise the usefulness of African values like Ubuntu, kin interest in marriage, and collegial governance.

83 Wa Thiong'o Decolonising the Mind; Gutto 2012 http://www.twn. my/title2/resurgence/2012/266-267/cover08.htm.

84 Gutto 2012 http://www.twn.my/title2/resurgence/2012/266-267/cover08.htm. 
Unfortunately, many Africans are so westernised that African values are barely known to them. In this sense, legal revisionism must contend with unrealistic expectations about the decolonisation of the law curriculum by unpacking the meaning of decolonisation.

If by decolonisation, we mean the replacement of the current law curriculum with an indigenous African law curriculum, then decolonisation is obviously unfeasible. Where would we find indigenous African laws? If we find these laws, would they be translated into English, French, and Portuguese to make them comprehensible to our students? If not translated, which African languages should be chosen to satisfy our multi-ethnic student populations? Importantly, where would we find qualified teachers to teach indigenous laws? ${ }^{85}$

If by decolonisation of the law curriculum, we mean the rejection of Western legal theories and methods, problems persist. Most law academics know only the Western way of scholarship. It would take decades of concerted advocacy, re-learning, and extensive indigenous scholarship to shift the dominance of Western knowledge to indigenous knowledge systems. Indeed, scholars' resistance to change is shamefully strong, as the Mamdani Affair showed. ${ }^{86} \mathrm{In}$ this regard, a higher education report in South Africa acknowledges: "Since colonial and apartheid times, there has been a mind-set within academia that has, in its crudest form, regarded intellectual activity as the preserve of white scholarship and the indigene as performing mundane functions." 87

However, if decolonisation primarily means emphasising indigenous knowledge, ${ }^{88}$ re-learning law's violent history, and consequently developing self-awareness of Africa's constructed identity, then we might realise that decolonisation of the law curriculum basically means a new way of teaching law.

\footnotetext{
$85 \quad$ Himonga 2010 PSILR 56.

86 In the mid-nineties, the University of Cape Town suspended Mahmood Mamdani, then AC Jordan Professor of African Studies and director of UCT's Centre for African Studies, for questioning the Eurocentric nature of African studies.

87 DoE Report of the Ministerial Committee 91.

88 Such knowledge belongs to those whom Garuba referred to as "previously devalued groups of people". See Garuba 2015 https://mg.co.za/article/2015-04-17-what-is-anafrican-curriculum/.
} 


\subsection{A new way of teaching}

This new way demands that we change the stories we tell students about their past, present, and future. It is inseparable from an exposition of law's violent history, ${ }^{89}$ law's role in ensuring justice, and its shameful role in perpetuating injustice. Although the meaning is contested, ${ }^{90}$ justice "casts the clearest light on the nature of law". ${ }^{91}$ Given that law reflects the state of society, law's pedagogy should expose the historical forces that drive unequal power relations. When law teachers debunk the fallacy of colonialism as a civilising mission and highlight the hardships caused by the imposition of capitalist economic systems on agrarian political economies, then curriculum decolonisation becomes evident as a struggle for justice and identity. The remainder of this article proposes the way forward.

\section{Way forward}

When students' demanded the decolonisation of the university curriculum, they also raised issues of patriarchy, sexism, and institutional racism. ${ }^{92}$ These issues arguably flow from our colonial/apartheid legacy of discrimination, division, and exploitation. We may characterise this legacy as injustice. Injustice is exacerbated by Africans' confused legal identity, and arguably drives the quest to change the narrative of the hegemony of Western knowledge in our higher education curriculum. ${ }^{93}$

Often scholars perceive injustice as the absence of justice ${ }^{94}$ However, this perception is narrow, for covert injustice arguably causes as much harm as overt injustice. For example, legal restrictions on land reclamations in South Africa is covert injustice because of the manner in which thousands of people were dispossessed of their lands in the $20^{\text {th }}$ century. Similarly, research funding restraints could be covert injustice for academic freedom, since they may suppress certain narratives. Even affirmative action in employment policies could constitute covert injustice if it prevents students from benefiting from quality teaching. ${ }^{95}$ Legal revisionist pedagogy therefore

\footnotetext{
89 Derrida "Force of Law".

90 For example, Cahn described injustice as "sympathetic reaction of outrage, horror, shock, resentment, and anger". See Cahn Sense of Injustice 24.

$91 \quad$ Cahn Sense of Injustice 2.

$92 \quad$ Molefe 2016 World Policy J 32.

93 Mamdani "Decolonising the Post-colonial University".

$94 \quad$ Fricker Epistemic Injustice.

95 McKaiser 2016 http://www.iol.co.za/news/epistemic-injustices-the-dark-side-ofacademic-freedom-2029747.
} 
encompasses the tripartite elements of unlearning, identity awareness, and remedial action.

\subsection{Elements of decolonisation}

These three elements resonate with Chilisa's five phases in the decolonisation process. ${ }^{96}$ Le Grange summarised these phases as: (1) rediscovery and recovery; (2) mourning; (3) dreaming; (4) commitment, and (5) action. ${ }^{97}$

The rediscovery and recovery phase encompasses the arguments made in this article. In this phase "colonised peoples rediscover and recover their own history, culture, language, and identity". ${ }^{98}$ Obviously, rediscovery will be slow if teachers have not experienced the rediscovery process themselves and acquired the ability 'metaphorically' to awaken others. Such teachers must, of course, be passionate and knowledgeable about legal history. A teacher that readily comes to mind is the late Harold Jack Simons, who is ably portrayed by Sachs in his 2016 book, We the People. ${ }^{99}$ Unfortunately, many (law) teachers regard Western knowledge as "the only basis for higher forms of thinking". ${ }^{100}$

Mourning is indignation at the "continued assault on the world's colonised/oppressed peoples' identities and social realities" and their ignorance of the root causes of their suffering. ${ }^{101}$ How can there be reaction without action? Today, many beneficiaries of our bequeathed social structure, especially wealthy landholders, are indifferent to the daily realities of the poor and marginalised among them. The decolonisation of the university curriculum would be cosmetic unless there was indignation at the status quo and concerted remedial action. These actions might be as overt as removing colonial/apartheid symbols of oppression, abolishing outsourcing, and dropping the demand for a driving license in employment application forms. They may also be as subtle as removing the word "comparative" from Legal History, and moving elective courses in the LLB curriculum down from the final year to afford students wider options for building their critical abilities in their formative years.

\footnotetext{
96 Chilisa Indigenous Research Methodologies.

97 Le Grange 2016 SAJHE 3.

98 Le Grange 2016 SAJHE 3.

99 See Sachs We, the People. For a biography of Jack Simons, see Sparg, Schreiner and Ansell Comrade Jack.

100 DoE Report of the Ministerial Committee 92.

101 Le Grange 2016 SAJHE 3.
} 
Remedial strategies involve dreaming, which "is when colonised peoples invoke their histories, worldviews, and indigenous knowledge systems to theorise and imagine alternative possibilities - in this instance a different curriculum."102 Dreaming enables students to challenge pedagogies that make them feel culturally inferior. Currently, the university curriculum does not encourage dreaming. As Heleta stated, it merely requires students "to learn to 'speak well' and gain skills and Eurocentric knowledge that will allow them to enter the marketplace but not allow them to fundamentally change the status quo in society and the economy."103 Regarding the status quo, dreaming must reject superficiality such as making African customary law a compulsory subject, or adding African Studies to the humanities curriculum. Rather, we must "rethink how the object of study itself is constituted", 104 since most of the curriculum is structured to suppress the dark history of colonialism in Africa. Only the sustained exposition of African legal history in classrooms will reveal the effects of "patriarchy, slavery, imperialism, colonialism, white supremacy and capitalism" on today's social relations. ${ }^{105}$

In this sense of invoking histories, dreaming arises from indignation, manifests in remedial action, and thrives on commitment. Le Grange explains:

Commitment is when academics/students become political activists who demonstrate the commitment to include the voices of the colonised, in this case, in the university curriculum. Action is the phase where dreams and commitments translate into [programmes] for social transformation. ${ }^{106}$

The above five phases are underlined by identity and injustice, two elements which demand a revisionist approach to the pedagogy of law. As shown below, revisionism is crucial to Africa's legal identity.

\subsection{Revisionism and African legal identity}

Western media usually go into overdrive when notable individuals such as Kofi Annan and Barack Obama tell Africans "to hold their political leaders and not colonialism - responsible for the civil wars and economic failures that ravage their lives". ${ }^{107}$ While it is mildly tempting to sympathise with this

\footnotetext{
102 Le Grange 2016 SAJHE 3.

103 Heleta 2016 Transformation in Higher Education 4.

104 Garuba 2015 https://mg.co.za/article/2015-04-17-what-is-an-african-curriculum/.

105 Molefe 2016 World Policy J 32.

$106 \quad$ Molefe 2016 World Policy J 32.

107 Crossette 1998 https://www.nytimes.com/1998/04/17/world/stop-blamingcolonialism-un-chief-tells-africa.html; Spillius 2009 https://www.telegraph.co.uk/ news/worldnews/africaandindianocean/5778804/Barack-Obama-tells-Africa-tostop-blaming-colonialism-for-problems.html.
} 
view, it is easier to dismiss it for its crass neglect of the pervasive impact of colonialism on the African psyche. Arguably, colonialism set up postindependence African states for failure. The disparate African tribes, which colonial authorities forcefully lumped together, share little sense of nationhood. Given the link between development and nationhood, it does not require acquaintance with rocket science to deduce that a lack of national identity contributes to corruption, conflict, and bad governance. ${ }^{108}$ For example, national independence struggles compelled leaders such as Nelson Mandela, Haile Selassie, Patrice Lumumba, Julius Nyerere, Kwame Nkrumah, Nnamdi Azikiwe, and even Kenneth Kaunda to genuinely bond with their people, thereby forging a strong sense of nationhood. This bonding was reflected in the modest good governance and economic development achieved in the early post-independence years, which eventually disappeared because they were, among other reasons, built on shaky foundations. ${ }^{109}$ Since we cannot negotiate the future without resolving the past, we must teach students how colonialism prevented Africans from negotiating their own borders, choosing their own leaders, and developing on their own terms.

While the decolonisation debate acknowledges the Eurocentric roots of the law curriculum, it tends to ignore the pervasive impact of colonial rule on indigenous African laws. For instance, our judicial system emulates the European structure, complete with ridiculous wigs and gowns, even in soaring temperatures. We have, of course, English, French, and Portuguese as court languages of record. Since the law curriculum is modelled on Western pedagogy, decolonising it requires wisdom because we can't "begin on a clean slate". ${ }^{110}$ However, we can deconstruct the writings on the slate and use a new narrative as the basis for structuring the future. For this restructuring, here are three proposals for African customary law.

\subsection{Pedagogic proposals}

First, African Customary Law and Legal History should be taught as standalone courses rather than as components of courses such as Jurisprudence, Introduction to Legal Pluralism or Legal Systems. Himonga observed that submerging customary law in other courses leaves it "to the discretion of individual course convenors ... [who may lack] sufficient

\footnotetext{
108 Wunsch and Olowu Failure of the Centralized State.

109 Another key cause of poor development is neo-imperialism. See, for example, ZackWilliams 2013 Rev Afr Political Econ.

110 Le Grange 2016 SAJHE 5.
} 
knowledge of African Customary Law to be able to integrate it into the course."111 The pedagogies of customary law and legal history should, of course, be interdisciplinary. They should draw from economics, sociology, and political science because lawyers are supposed to know a little about everything. Drawing from other disciplines in the teaching of customary law would reveal the historical forces that shaped and still shape its construction. Since law is inseparable from society, students must be acquainted with how legal history reeks of dominion, injustice, and struggle. ${ }^{112} \mathrm{~A}$ broad knowledge of legal history will help them to comprehend the development of concepts such as individual rights, the land tenure system, legal positivism, and evidentiary rules. These concepts are useful for understanding why and when norms outlive their usefulness. In sum, an interdisciplinary approach to the pedagogy of African customary law will reveal "the perspectives of the colonised and the coloniser, their interwoven histories, [and] their discursive entanglements". ${ }^{113}$ This interdisciplinary learning is best suited to the second proposal of this article.

Law students must be taught empirical research methodologies, especially some relatively new methods such as storytelling, oral history, and participatory action research. In this sense, the pedagogy of African customary law should de-emphasise rules and conflict of laws. Rather, teaching should focus on the processual nature of indigenous law, its research methodologies, and its foundational values in marriage, succession, land, contract, religion/rituals, traditional authority, and dispute resolution. One way of bringing these values to the fore and promoting the empirical research skills of law students is to send them on research visits to their communities during their long vacation as part of their continuous assessment programme. Presently, the teaching of African customary law in many universities may as well pass for an Introduction to Legal Pluralism, ${ }^{114}$ while the current assessment model is overly rule-focussed. To reverse it, assessments should de-emphasise legislation and case law and favour research papers and mock interviews.

Finally, the pedagogic labels of official and living customary law should be dropped because they obscure the adaptive nature of legal pluralism in Africa. As argued here, customary law emerged from the encounter of indigenous African laws with European ways of life. Accordingly, the precedents and codifications which are labelled as official customary law

\footnotetext{
$111 \quad$ Himonga 2010 PSILR 55-56.

112 Arendt "Crisis in Education".

113 Garuba 2015 https://mg.co.za/article/2015-04-17-what-is-an-african-curriculum/.

114 Mchombu "Comparison of Customary Law Programmes".
} 
are products of this encounter. Customs which communities apply in their pre-colonial form (such as male primogeniture) constitute indigenous law. In sum, pedagogic descriptions of African customary law should base their definition on people's adaptation of indigenous norms to socio-economic changes.

\subsection{Closing remarks}

An adaptation pedagogy constitutes a reality check in the debate on the decolonisation of law. Obviously, the bulk of the law curriculum cannot be changed because African legal systems are founded on irreversible colonial legacies. Thus, hypocritical attitudes to decolonisation should be avoided, since everyone has embraced many products of colonial rule ranging from the way we dress to how we eat, think, and speak. While Africans cannot escape the changes brought by colonialism, they can embrace the challenge of self-discovery and new identity. Law teachers can acknowledge, explain, and situate social problems within their historical contexts. ${ }^{115}$ Thereafter, they can use the foundational values of indigenous law and constitutional bills of rights as the basis of Africa's new legal identity. Indeed, if this task is handled well, it could offer a platform for integrating customary law with state law. In other words, a policy focus on people's adaptation of indigenous laws to socio-economic changes could help in the evolution of a common law in African countries.

For evidence in support of this suggestion, we may look to the mutation of the customary law of the English people. The English Common Law is an amalgam of indigenous laws and the laws introduced by the Romans, Germanic tribes, and Norse tribes from ancient Scandinavia, who conquered Britain for several centuries beginning in $43 \mathrm{CE}$. Indeed, "the [English] common law tradition itself is best understood, employed, and developed when it is regarded fundamentally as a system of customary law."116 Already, indigenous African laws have been profoundly altered by legislation regulating marriage, land, succession, and property. ${ }^{117}$ Judges are now accustomed to interpreting customs in accordance with the bill of rights. Rural women and civil society groups increasingly assert the principles of human rights in the application of indigenous law. ${ }^{118}$ Self-

\footnotetext{
115 In South Africa, an obvious example is land redistribution.

116 Aleck 1997 QUTLJ 139.

117 Examples include South Africa's unified marriage bill and Kenya's Marriage Law of 2014, a comprehensive legislation that consolidates disparate laws regulating religious, indigenous, and civil marriages and divorces. 
evidently, the coercive influence of state laws, coupled with people's adaptation of customs to socio-economic changes, will eventually extinguish precolonial indigenous norms. Accordingly, founding the pedagogy of African customary law on an adaptation framework offers a sensible theoretical roadmap for legal integration, especially in South Africa.

\section{Bibliography}

\section{Literature}

Achebe Farmers, Traders, Warriors, and Kings

Achebe $N$ Farmers, Traders, Warriors, and Kings: Female Power and Authority in Northern Igboland, 1900-1960 (Heinemann London 2005)

Afigbo $1965 \mathrm{JHSN}$

Afigbo AE "Herbert Richmond Palmer and Indirect Rule in Eastern Nigeria: 1915-1928" 1965 JHSN 295-312

Afigbo Warrant Chiefs

Afigbo E The Warrant Chiefs: Indirect Rule in Southeastern Nigeria: 1891 1929 (Longman London 1972)

Akoma 2009 Res Afr Lit

Akoma C "Verbal Miscues or Cultural Agency? Icheoku: An Introduction" 2009 Res Afr Lit 86-96

Aleck 1997 QUTLJ

Aleck $\mathrm{J}$ "Beyond Recognition: Contemporary Jurisprudence in the Pacific Islands and the Common Law Tradition" 1997 QUTLJ 137-143

Allot "Future of African Law"

Allot A "The Future of African Law" in Kuper $\mathrm{H}$ and Kuper L African Law: Adaptation and Development (University of California Press Berkeley 1965) 216-242

Amadiume Male Daughters, Female Husbands

Amadiume I Male Daughters, Female Husbands: Gender and Sex in an African Society (Zed Books London 1989)

Arendt "Crisis in Education"

Arendt H "The Crisis in Education" (1954) republished in Arendt H Between Past and Future (Viking Press New York 1961) 170-193 
Bain 2003 Int Relat

Bain W "The Political Theory of Trusteeship and the Twilight of International Equality" 2003 Int Relat 59-77

Bekker and Van Niekerk 2010 THRHR

Bekker $\mathrm{J}$ and Van Niekerk GJ "Broadening the Divide between Official and Living Customary Law" 2010 THRHR 679-689

Bekker and Maithufi 1992 JJS

Bekker JC and Maithufi IP "The Dichotomy between 'Official Customary Law' and 'Non-official Customary Law'' 1992 JJS 47-60

Bennett "'Official' vs 'Living' Customary Law"

Bennett TW "'Official' vs 'Living' Customary Law: Dilemmas of Description and Recognition" in Claassens A and Cousins B (eds) Land, Power and Custom: Controversies Generated by South Africa's Communal Land Rights Act (Juta Cape Town 2008) 138-153

Boughey and McKenna 2016 CriSTaL

Boughey $\mathrm{C}$ and McKenna S "Academic Literacy and the Decontextualised Learner" 2016 CriSTaL 1-9

Cahn Sense of Injustice

Cahn EM The Sense of Injustice (New York University Press New York 1949)

Césaire "Discourse on Colonialism"

Kelley RDG "A Poetics of Anticolonialism" in Césaire A and Kelley RDG Discourse on Colonialism; A Poetics of Anticolonialism (Monthly Review Press New York 2000) 29-78

Chanock 1989 IJL\&F

Chanock M "Neither Customary nor Legal: African Customary Law in an Era of Family Law Reform" 1989 IJL\&F 72-88

Chanock Law, Custom and Social Order

Chanock M Law, Custom and Social Order: The Colonial Experience in Malawi and Zambia (Cambridge University Press Cambridge 1998)

Chanock Making of South African Legal Culture

Chanock M The Making of South African Legal Culture, 1902-1936: Fear, Favour and Prejudice (Cambridge University Press Cambridge 2001) 
Chilisa Indigenous Research Methodologies

Chilisa B Indigenous Research Methodologies (SAGE Thousand Oaks 2012)

Claassens 2011 Acta Juridica

Claassens A "Contested Power and Apartheid Tribal Boundaries: The Implications of 'Living Customary Law' for Indigenous Accountability Mechanisms" 2011 Acta Juridica 174-209

Claassens 2013 J Agrar Change

Claassens A "Recent Changes in Women's Land Rights and Contested Customary Law in South Africa" 2013 J Agrar Change 71-92

Claassens and Weeks 2009 SAJHR

Claassens A and Weeks MS "Rural Women Redefining Land Rights in the Context of Living Customary Law" 2009 SAJHR 491-516

Commission of Enquiry Report

Commission of Enquiry Appointed to Inquire into the Disturbance in the Calabar and Owerri Provinces Report, December 1929 (Sessional Paper No 28) (Government Printer Lagos 1930)

Costa 1998 SAJHR

Costa A "The Myth of Customary Law" 1998 SAJHR 525-538

DoE Report of the Ministerial Committee

Department of Education Report of the Ministerial Committee on Transformation and Social Cohesion and the Elimination of Discrimination in Public Higher Education Institutions (Department of Education Pretoria 2008)

Derrida "Force of Law"

Derrida J "Force of Law: The 'Mystical Foundation of Authority"' in Cornell D, Rosenfield M and Carlson D (eds) Deconstruction and the Possibility of Justice (Routledge London 1992) ch 1

Diala 2014 AHRLJ

Diala AC "Reform of the Customary Law of Inheritance in Nigeria: Lessons from South Africa" 2014 AHRLJ 633-654

Diala 2017 J Legal Plur

Diala AC "The Concept of Living Customary Law: A Critique" 2017 J Legal Plur 143-165 
Douzinas 2002 MULR

Douzinas C "The End(s) of Human Rights" 2002 MULR 445-465

Fricker Epistemic Injustice

Fricker M Epistemic Injustice: Power and the Ethics of Knowing (Oxford University Press Oxford 2007)

Greenbaum 2012 Stell LR

Greenbaum L "Current Issues in Legal Education: A Comparative Review" 2012 Stell LR 16-39

Grumet "Restitution and Reconstruction of Educational Experience" Grumet MR "Restitution and Reconstruction of Educational Experience: An Autobiographical Method for Curriculum Theory" in Lawn M and Barton L (eds) Rethinking Curriculum Studies: A Radical Approach (Croom Helm London 1981) 115-130

Hafkin and Bay Women in Africa

Hafkin NJ and Bay EG (eds) Women in Africa: Studies in Social and Economic Change (Stanford University Press Stanford 1976)

Hart 1958 Harv L Rev

Hart HLA "Positivism and the Separation of Law and Morals" 1958 Harv L Rev 593-629

Heleta 2016 Transformation in Higher Education

Heleta S "Decolonisation of Higher Education: Dismantling Epistemic Violence and Eurocentrism in South Africa" 2016 Transformation in Higher Education 1-8

Himonga "Future of Living Customary Law"

Himonga CN "The Future of Living Customary Law in African Legal Systems in the Twenty-First Century and Beyond with Special Reference to South Africa" in Fenrich J, Galizzi P and Higgins T (eds) The Future of Customary Law (Cambridge University Press Cambridge 2011) 31-57

Himonga 2010 PSILR

Himonga CN "Goals and Objectives of Law Schools in their Primary Role of Educating Students: South Africa - The University of Cape Town School of Law Experience" 2010 PSILR 41-60 
Himonga and Bosch 2000 SALJ

Himonga $\mathrm{CN}$ and Bosch C "The Application of African Customary Law under the Constitution of South Africa: Problems Solved or just Beginning?" 2000 SALJ 306-341

Hinz "Bhe $v$ the Magistrate of Khayelitsha"

Hinz MO "Bhe $v$ the Magistrate of Khayelitsha, or: African Customary Law before the Constitution" in Hinz M and Patemann $\mathrm{H}$ (eds) The Shade of New Leaves: Governance in Traditional Authority: A Southern African Perspective (LIT Verlag Berlin 2006) 267-286

Hochschild King Leopold's Ghost

Hochschild A King Leopold's Ghost: A Story of Greed, Terror, and Heroism in Colonial Africa (Houghton Mifflin Boston 1999)

Holleman 1973 Law \& Soc Rev

Holleman JF "Trouble-cases and Trouble-less Cases in the Study of Customary Law and Legal Reform" 1973 Law \& Soc Rev 585-609

Huebner "Poetry and Power" Huebner DE "Poetry and Power: The Lure of Curricular Development" in Huebner DE; Hillis V and Pinar W (eds) The Lure of the Transcendent: Collected Essays by Dwayne E Huebner (Psychology Press London 1999) 231-240

Hund 1998 ARSP

Hund J '"Customary Law is what People Say it is' - HLA Hart's Contribution to Legal Anthropology" 1998 ARSP 420-433

lya 2003 Third World Legal Stud

lya PF "From Lecture Room to Practice: Addressing the Challenges of Reconstructing and Regulating Legal Education and Legal Practice in the New South Africa" 2003 Third World Legal Stud 141-160

lya $2001 J$ Leg Ed

lya PF "The Legal System and Legal Education in Southern Africa: Past Influences and Current Challenges" $2001 \mathrm{~J}$ Leg Ed 355-362

Kelley "Poetics of Anticolonialism"

Kelley RDG "A Poetics of Anticolonialism" in Césaire A and Kelley RDG Discourse on Colonialism; A Poetics of Anticolonialism (Monthly Review Press New York 2000) 7-28 
Koyana Customary Law

Koyana DS Customary Law in a Changing Society (Juta Cape Town 1980)

Kunbuor 2002 Journal of Dagaare Studies

Kunbuor, B "Customary Law of the Dagara of Northern Ghana: Indigenous

Rules or a Social Construction" 2002 Journal of Dagaare Studies 1-21

Kult 2000 Ind Int'l \& Comp L Rev

Kult AP "Intestate Succession in South Africa: The Westernization of Customary Law Practices within a Modern Constitutional Framework" 2000 Ind Int'I \& Comp L Rev697-729

Le Grange 2016 SAJHE

Le Grange L "Decolonising the University Curriculum" 2016 SAJHE 1-12

Letsekha 2013 IJTL

Letsekha $T$ "Revisiting the Debate on the Africanisation of Higher Education: An Appeal for a Conceptual Shift" 2013 IJTL 5-18

Mamdani Citizen and Subject

Mamdani M Citizen and Subject: Contemporary Africa and the Legacy of Late Colonialism (Princeton University Press Princeton 1996)

Mamdani "Decolonising the Post-colonial University"

Mamdani M "Decolonising the Post-colonial University" TB Davie Memorial Lecture (22 August 2017 University of Cape Town)

Mamdani Define and Rule

Mamdani M Define and Rule: Native as Political Identity (Harvard University Press Cambridge 2012)

Masilela "African Intellectual and Literary Responses"

Masilela $N$ "African Intellectual and Literary Responses to Colonial Modernity in South Africa" in Limb P and Etherington N (eds) Grappling with the Beast: Indigenous Southern African Responses to Colonialism, 18401930 (Brill Publishing 2010) 245-275

Mbatha 2002 SAJHR

Mbatha L "Reforming the Customary Law of Succession" 2002 SAJHR 259286

Mbembe 2016 AHHE

Mbembe A "Decolonising the University: New Directions" 2016 AHHE 2945 
Mchombu "Comparison of Customary Law Programmes"

Mchombu C "A Comparison of Customary Law Programmes in Southern African Universities" in Hinz M and Patemann H (eds) The Shade of New Leaves: Governance in Traditional Authority: A Southern African Perspective (LIT Verlag Berlin 2006) 429-438

Meredith Fate of Africa

Meredith M The Fate of Africa: A History of the Continent since Independence (Public Affairs New York 2011)

Modiri 2014 Acta Academica

Modiri J "The Crises in Legal Education" 2014 Acta Academica 1-24

Mokgoro 1998 PELJ

Mokgoro Y "Ubuntu and the Law in South Africa" 1998 PELJ 1-11

Molefe 2016 World Policy J

Molefe TO "Oppression must Fall: South Africa's Revolution in Theory" 2016 World Policy J 30-37

Mudimbe 1985 Afr Stud Rev

Mudimbe VY "African Gnosis Philosophy and the Order of Knowledge: An Introduction" 1985 Afr Stud Rev 149-233

Muvangua and Cornell Ubuntu and the Law

Muvangua $\mathrm{N}$ and Cornell D (eds) Ubuntu and the Law: African Ideals and Postapartheid Jurisprudence (Fordham University Press New York 2012)

Nhlapo 1991 Acta Juridica

Nhlapo TR "The African Family and Women's Rights: Friends or Foes" 1991 Acta Juridica 135-146

Nwanesi Development, Micro-credit and Women's Empowerment Nwanesi PK Development, Micro-credit and Women's Empowerment: A Case Study of Market and Rural Women in Southern Nigeria (PhDdissertation University of Canterbury 2006)

Odora-Hoppers and Richards Rethinking Thinking Odora-Hoppers C and Richards H Rethinking Thinking: Modernity's 'Other' and the Transformation of the University (UNISA Press Pretoria 2011) 
Okoro Customary Laws of Succession

Okoro N The Customary Laws of Succession in Eastern Nigeria and the Statutory and Judicial Rules Governing their Application (Sweet and Maxwell London 1966)

Okoth-Ogendo 1984 Int'l J Soc L

Okoth-Ogendo HW "Development and the Legal Process in Kenya: An Analysis of the Role of Law in Rural Development Administration" 1984 Int'I $J$ Soc L 59-83

Pieterse 2000 De Jure

Pieterse M "Killing it Softly: Customary Law in the New Constitutional Order" 2000 De Jure 35-53

Pietsch Empire of Scholars

Pietsch T Empire of Scholars: Universities, Networks and the British Academic World, 1850-1939 (Manchester University Press Manchester 2013)

Pinar What is Curriculum Theory?

Pinar WF What is Curriculum Theory? (Routledge London 2012)

Plunkett Concise History of English Law

Plunkett TF Concise History of the English Law (Little, Brown Boston 1956)

Pollock and Maitland History of English Law

Pollock F and Maitland FW The History of English Law before the Time of Edward I (Cambridge University Press Cambridge 1895)

Rautenbach and Du Plessis "Reform of the South African Customary Law of Succession"

Rautenbach C and Du Plessis W "Reform of the South African Customary Law of Succession: Final Nails in the Customary Law Coffin?" in Fenrich J, Galizzi P and Higgins T (eds) The Future of Customary Law (Cambridge University Press Cambridge 2011) 336-362

Readings University in Ruins

Readings B The University in Ruins (Harvard University Press Cambridge 1996)

Sachs We, the People

Sachs A We, the People: Insights of an Activist Judge (Wits University Press Johannesburg 2016) 
Smith Decolonising Methodologies

Smith L Decolonising Methodologies: Research and Indigenous Peoples (Zed Books London 1999)

Snyder $1981 \mathrm{~J}$ Legal Plur

Snyder FG "Colonialism and Legal Form: The Creation of 'Customary Law' in Senegal" 1981 J Legal Plur 49-90

Sparg, Schreiner and Ansell Comrade Jack

Sparg M, Schreiner J and Ansell G (eds) Comrade Jack: The Political Lectures and Diary of Jack Simons, Novo Catengue (Real African Publishers Johannesburg 2001)

Van Niekerk 2012 SUBB Jurisprudentia

Van Niekerk GJ "Reflections on the Interplay of African Customary Law and State Law in South Africa" 2012 SUBB Jurisprudentia 5-20

Villa-Vicencio $2000 \mathrm{~J}$ L \& Relig

Villa-Vicencio C "Christianity and Human Rights" 2000 J L \& Relig 579-600

Wa Thiong'o Decolonising the Mind

Wa Thiong'o N Decolonising the Mind: The Politics of Language in African Literature (East African Publishers Nairobi 1994)

Walker Women and Gender

Walker C (ed) Women and Gender in Southern Africa to 1945 (New Africa Books Cape Town 1990)

Wildenboer 2010 Fundamina

Wildenboer $L$ "The Origins of the Division of the Legal Profession in South Africa: A Brief Overview" 2010 Fundamina: A Journal of Legal History 199225

Woodman 1996 J Afr L

Woodman GR "Legal Pluralism and the Search for Justice" $1996 \mathrm{~J}$ Afr $L$ 152-167

Wunsch and Olowu Failure of the Centralized State

Wunsch JS and Olowu D (ed) The Failure of the Centralized State: Institutions and Self-governance in Africa (Westview Press Boulder 1990)

Zack-Williams 2013 Rev Afr Political Econ

Zack-Williams A "Neo-imperialism and African Development" 2013 Rev Afr Political Econ 179-184 


\section{Case law}

Bhe v Magistrate, Khayelitsha; Shibi v Sithole; South African Human Rights Commission v President of the Republic of South Africa 20051 SA 580 (CC)

Onyibor Anekwe v Mrs Maria Nweke 2014 All FWLR (Pt 739) 1154

Ukeje v Ukeje 201411 NWLR (Pt 1418) 384-414

\section{Legislation}

Promotion of Equality and Prevention of Unfair Discrimination Act 4 of 2000 Recognition of Customary Marriages Act 120 of 1998

Reform of Customary Law of Succession and Regulation of Related Matters Act 11 of 2009

\section{Internet sources}

Crossette 1998 https://www.nytimes.com/1998/04/17/world/stop-blamingcolonialism-un-chief-tells-africa.html

Crossette B "Stop Blaming Colonialism, UN Chief Tells Africa" The New York Times (17 April 1998) https://www.nytimes.com/ 1998/04/17/world/stop-blaming-colonialism-un-chief-tells-africa.html accessed 11 September 2019

Disemelo 2015 https://mg.co.za/article/2015-10-29-student-protests-areabout-much-more-than-just-feesmustfall

Disemelo $\mathrm{K}$ "Student Protests are about Much More than just \#FeesMustFall" Mail and Guardian (29 October 2015) https://mg.co.za/article/2015-10-29-student-protests-are-about-muchmore-than-just-feesmustfall accessed 10 September 2019

Dummett 2004 http://news.bbc.co.uk/2/hi/africa/3516965.stm Dummett M "King Leopold's Legacy of DR Congo Violence" BBC News (24 February 2004) http://news.bbc.co.uk/2/hi/africa/3516965.stm accessed 11 September 2019

Garuba 2015 https://mg.co.za/article/2015-04-17-what-is-an-africancurriculum/

Garuba $\mathrm{H}$ "What is an African Curriculum?" Mail and Guardian (17 April 2015) https://mg.co.za/article/2015-04-17-what-is-an-african-curriculum/ accessed 10 September 2019 
Gutto $2012 \quad$ http://www.twn.my/title2/resurgence/2012/266267/cover08.htm

Gutto S "Decolonising the Law: Do We have a Choice?" 2012 Third World Resurgence $\quad 42-43 \quad \mathrm{http}: / / \mathrm{www}$. twn.my/title2/resurgence/2012/266267/cover08.htm accessed 11 September 2019

McKaiser 2016 http://www.iol.co.za/news/epistemic-injustices-the-darkside-of-academic-freedom-2029747

McKaiser E 2016 Epistemic Injustices: The Dark Side of Academic Freedom - DCS Oosthuizen Academic Freedom Memorial Lecture, Rhodes University (30 May 2016) http://www.iol.co.za/news/epistemic-injusticesthe-dark-side-of-academic-freedom-2029747 accessed 11 September 2019

Mgqwashu 2016 https://theconversation.com/universities-cant-decolonisethe-curriculum-without-defining-it-first-63948

Mgqwashu E 2016 Universities can't Decolonise the Curriculum without Defining it First https://theconversation.com/universities-cant-decolonisethe-curriculum-without-defining-it-first-63948 accessed 11 September 2019

Rincon 2015 https://www.bbc.com/news/science-environment-33462184 Rincon P "Why is Pluto no Longer a Planet?" BBC News (13 July 2015) https://www.bbc.com/news/science-environment-33462184 accessed 11 September 2019

Robinson 2017 https://www.currentaffairs.org/2017/09/a-quick-reminder-ofwhy-colonialism-was-bad

Robinson NJ "A Quick Reminder of why Colonialism was Bad" Current Affairs (14 September 2017) https://www.currentaffairs.org/2017/09/aquick-reminder-of-why-colonialism-was-bad accessed 24 September 2019

Spillius 2009 https://www.telegraph.co.uk/news/worldnews/africaan dindianocean/5778804/Barack-Obama-tells-Africa-to-stop-blamingcolonialism-for-problems.html

Spillius A "Barack Obama tells Africa to Stop Blaming Colonialism for Problems" The Telegraph (9 July 2009) https://www.telegraph.co.uk/ news/worldnews/africaandindianocean/5778804/Barack-Obama-tells-

Africa-to-stop-blaming-colonialism-for-problems.html accessed 11 September 2019 
Wingfield $2017 \mathrm{http}: / /$ theconversation.com/what-decolonised-educationshould-and-shouldnt-mean-72597

Wingfield B 2017 What 'Decolonised Education' should and shouldn't Mean http://theconversation.com/what-decolonised-education-should-andshouldnt-mean-72597 accessed 11 September 2019

\section{List of Abbreviations}

$\begin{array}{ll}\text { Afr Stud Rev } & \text { African Studies Review } \\ \text { AHHE } & \text { Arts and Humanities in Higher Education } \\ \text { AHRLJ } & \text { African Human Rights Law Journal } \\ \text { ARSP } & \text { Archives for Philosophy of Law and Social } \\ & \text { Philosophy } \\ \text { CriSTaL } & \text { Critical Studies in Teaching and Learning } \\ \text { DoE } & \text { Department of Education } \\ \text { Harv L Rev } & \text { Harvard Law Review } \\ \text { IJL\&F } & \text { International Journal of Law and Family } \\ \text { IJTL } & \text { Independent Journal of Teaching and } \\ & \text { Learning } \\ \text { Ind Int'l \& Comp L Rev } & \text { Indiana International and Comparative Law } \\ & \text { Review } \\ \text { Int Relat } & \text { International Relations } \\ \text { Int'I J Soc L } & \text { International Journal of the Sociology of } \\ & \text { Law } \\ \text { J Afr L } & \text { Journal of African Law } \\ \text { J Agrar Change } & \text { Journal of Agrarian Change } \\ \text { J L \& Relig } & \text { Journal of Law and Religion } \\ \text { J Leg Ed } & \text { Journal of Legal Education } \\ \text { J Legal Plur } & \text { Journal of Legal Pluralism and Unofficial } \\ & \text { Law } \\ \text { JHSN } & \text { Journal of the Historical Society of Nigeria } \\ \text { JJS } & \text { Journal for Juridical Science } \\ \text { Law \& Soc Rev } & \text { Law and Society Review } \\ \text { MULR } & \text { Melbourne University Law Review } \\ \text { PELJ } & \text { Potchefstroom Electronic Law Journal } \\ \text { PSILR } & \text { Pennsylvania State International Law } \\ & \text { Review } \\ \text { QUTLJ } & \text { Queensland University of Technology Law } \\ & \text { Journal } \\ \text { Res Afr Lit } & \text { Research in African Literatures } \\ & \end{array}$


Rev Afr Political Econ

SAJHE

SAJHR

SALJ

Stell LR

SUBB Jurisprudentia

Third World Legal Stud THRHR

WLSA

World Policy J
Review of African Political Economy South African Journal of Higher Education South African Journal on Human Rights South African Law Journal Stellenbosch Law Review Studia Universitatis Babes Bolyailurisprudentia

Third World Legal Studies Tydskrif vir Hedendaagse RomeinsHollandse Reg

Women and Law in Southern Africa Research and Education Trust World Policy Journal 